\title{
Pemanfaatan Jamur Simbion Sponge dalam Bioisomerasi Asam Lemak pada Dedak untuk Menghasilkan Asam Lemak Cis
}

\author{
Agus Trianto 1,2*, Sri Sedjati', Ocky Karna Radjasa1,3, Rachmat Afriyanto', Sakti \\ Imam Muchlisin 3 , Septhy Kusuma Radjasa ${ }^{3}$, Muhammad Syaifudien Bahry ${ }^{2}$ \\ 'Departemen IImu Kelautan, Fakultas Perikanan dan IlmuKelautan, Universitas Diponegoro \\ 2Natural Product Laboratory, Laboratorium Terpadu, Universitas Diponegoro \\ 3Tropical Marine Biodiversity Laboratorium Terpadu, Universitas Diponegoro \\ JI. Prof. Soedarto, SH. Tembalang, Semarang 50275 Indonesia \\ Email : agustrianto.undip@gmail.com
}

\begin{abstract}
Utilization of Sponges Symbiotic Fungus in the Bioisomeration of Fatty Acids in Brans to Produce Cis Fatty Acid
\end{abstract}

Trans fatty acids are known to have a negative impact on human health such as triggering the coronary heart and blood vessel related diseases. However, many food and animal feed contain trans fatty acids. Bran, which is widely used as animal feed has high fatty acid content and the majority are trans fatty acids. This study aims to determine the potential of Trichoderma harzanum, a sponge symbiont fungus, in the process of fatty acid bioconversion in bran. Bran was fermented in saline and non-salin condition for 15 days in the room temperature. Both fermented and not bran was extracted with methanol, and the extracts were concentrated with rotary evaporator. Fatty acid extracts were analyzed on the GC with hydrolysis and methylation as pretreatments. The test results showed the fatty acid composition changed, and the was formation of new fatty acids. The bioisomeration process occurs in the Trans-9-Elaidic acid Methyl esther into Cis9-Oleic Methyl ester. Cis-9-oleic acid is known as oleic acid which is widely found in olive and sunflowers oil. The fungus has potential as biocatalys for production of cis fatty acid.

Keyword : sponge; symbiotic fungus; trans-cis isomeration; fatty acid

\begin{abstract}
Abstrak
Asam lemak trans dikenal mempunyai dampak negatif terhadap kesehatan manusia seperti memicu terjadinya penyakit jantung koroner dan penyakit terkait pembuluh darah. Namun asam lemak trans banyak terkandung dalam berbagai jenis bahan makanan maupun pakan ternak diantaranya adalah dedak. Dedak banyak digunakan sebagai pakan ternak mempunyai kandungan asam lemak yang tinggi dan mayoritas adalah asam lemak trans. Penelitian ini bertujuan untuk mengetahui potensi jamur simbion spons Trichoderma harzanum dalam proses biokonversi asam lemak pada dedak. Fermentasi dedak dilakukan dalam kondisi salin dan unsalin selama 15 hari pada suhu ruang. Dedak yang difermentasi maupun tidak kemudian diekstrak dengan metanol kemudian dipekatkan dengan rotari eveporator. Ekstrak asam lemak degan GC dengan pre-treatment meliputi hidrolisis dan metilasi. Hasil uji menunjukan adanya perubahan komposisi dan terbentuknya asam lemak baru. Proses bioisomerasi terjadi pada Trans-9-Elaidic acid Methyl estermenjadi Cis-9-Oleic Methyl ester. Cis-9-oleic acid yang dikenal dengan asam oleat yang banyak terdapat dalam minyak zaitun dan bunga matahari. Jamur T. Harzianum mempunyai potensi sebagai biokatalis untuk memproduksi asam lemak cis.
\end{abstract}

Kata kunci : Sponge; jamur simbion; tran-cis isomerasi; asam lemak 


\section{PENDAHULUAN}

Keanekaragaman hayati laut Indonesia memiliki potensi yang sangat besar untuk menghasilkan metabolit sekunder yang dapat dimanfaatkan sebagai sumber bahan bioaktif. Spons merupakan merupakan biota filter feeder yang mengandung mikroba laut hingga $40 \%$ dari volumenya (Murniasih et al., 2016). Jamur simbion merupakan salah satu sumber metabolit sekunder yang sangat produktif (Amira et al., 2009). Pada dekade terakhir banyak penelitian yang melaporkan bahwa jamur yang bersimbiosis dengan beberapa invertebrata laut seperti spons diketahui dapat digunakan sebagai sumber baru dari senyawa bioaktif yang dapat digunakan sebagai anti tumor, anti bakteri, antivirus, anti jamur, anti kanker dan anti inflamasi (Swathi, 2013). Jamur yang berasal dari laut banyak menghasilkan senyawa seperti poliketida, turunan alkaloid, terpen, peptide dan senyawa lain serta mengahsilkan enzim seperti amilase (Swathi, 2013)

Asam lemak trans merupakan asam lemak tak jenuh yang memiiliki satu ikatan rangkap atau lebih (Mazidi et al. 2018) Penelitian menunjukkan bahwa keberadaan asam lemak trans dapat menimbulkan dampak negatif pada kesehatan seperti memicu terjadinya penyakit jantung koroner dan penyakit lainnya. Beberapa penelitian menunjukkan pengaruh asam lemak trans lebih buruk jika dibandingkan efek negative asam lemak jenuh dan kolesterol (Wikanta, 2012).

Jumlah asam lemak trans dapat meningkat akibat proses hidrogenasi dan pemanasan pada suhu tinggi. Proses hidrogenasi ditemukan oleh Norman pada tahun 1903. Proses ini terdiri dari pemanasan dengan adanya higrogen elementer yang dibantu oleh katalisator logam biasanya mengunakan nikel. Hasil higrogen parsial ialah a) terjadinya penjenuhan dari ikatan tak jenuh asam lemak, b) isomerisasi ikatan rengkap bentuk cis (alami) menjadi isomer trans, dan c) perubahan posisi ikatan rangkap (Silalahi et al., 2002).

Dedak padi merupakan limbah hasil penggilingan padi menjadi beras. Dedak banyak dimanfaatkan sebagai pakan ternak. Komponen utama dedak adalah minyak, protein, karbohidrat dan mineral (Hadipernata et al., 2012). Dedak mengandung minyak yang cukup tinggi yaitu $15-25 \%$ dan tersusun atas asam lemak palmitat, oleat dan linoleat berturut-turut berkisar antara: $12-18 \% ; 40-50 \%$ dan $30-35 \%$ (Wang et al., 2017). Minyak dedak digolongkan sebagai asam lemak tak jenuh yang memliki nilai nutrisi yang tinggi, sehingga dalam pemanfaatannya tidak hanya sebagai bahan minyak goreng saja namun dapat diproses lebih lanjut menjadi berbagai macam produk turuanannya. Namun, asam lemak yang terkandung dalam dedak merupakan asam lemak trans yang dapat memberikan pengaruh negatif seperti yang telah disebutkan jika dikonsumsi (Hadipernata, 2012).

Penelitian tentang pemanfaatan jamur simbion sponge dalam bioisomerasi asam lemak pada dedak ini dilakukan dengan harapan dapat diketahui gambaran mengenai proses bioisomerisasi asam lemak trans yang berbahaya bagi kesehatan jika dikonsumsi menjadi asam lemak cis yang lebih mudah bereaksi dan minim efek samping bagi kesehatan.

\section{MATERI DAN METODE}

Media penanaman jamur Tricoderma harzianum adalah $200 \mathrm{~g}$ bekatul, 2 g yeast, $5 \mathrm{~g}$ pepton, $200 \mathrm{ml}$ air laut Autoclave $121^{\circ} \mathrm{C} 15$ menit. Inokulasi jamur Tricoderma harzianum dilakukan di dalam bok plastik steril.

\section{Panen}

Proses panen dilakukan di hari ke 15. Ekstraksi dilakukan dengan merendam jamur yang tumbuh pada media dedak dengan menggunakan pelarut methanol. Dilakukan penggantian pelarut setiap 1×24 jam selama 2 kali. Filtrat maserasi kemudian dipekatkan dengan vacuum rotary evaporator untuk mendapatkan crude extract.

\section{Analisis Asam lemak jenuh dan tidak jenuh Hidrolisis}

Ekstrak diambil dan ditambahkan $3 \mathrm{ml}$ $\mathrm{HCl}$ pekat kemudian dipanaskan pada waterbath suhu $80^{\circ} \mathrm{C}$. Sampel dipanaskan sampai mendidih selama 2 jam kemudian 
didinginkan. Ekstrak ditambahkan $5 \mathrm{ml}$ diethyl ether dan petroleum ether (1:1). Vortex kemudian diamkan sampai mengendap kemudian diambil lapisan atas yang merupakan minyak. Sampel kemudian divapkan dalam waterbath dengan bantuan gas $\mathrm{N}_{2}$.

\section{Metilasi}

Sampel diambil $0,5 \mathrm{~mL}$ dan ditambahkan 1,5 $\mathrm{mL}$ larutan Natrium metanolik. Sampel kemudian dipanaskan pada suhu $60 \square$ C selama 5-10 menit sambil digojok dan didinginkan. Larutan ditambahkan $2 \mathrm{~mL}$ Boron trifluoride metanoat, dianaskan pada suhu $60^{\circ} \mathrm{C}$ selama 5-10 menit dan didinginkan. Sampel diekstrak dengan $1 \mathrm{~mL}$ Heptan dan $1 \mathrm{~mL}$ $\mathrm{NaCl}$ jenuh. Lapisan atas diambil dan dimasukkan ke dalam tube untuk kemudian diinjeksikan ke GC sebanyak $1 \mu \mathrm{L}$ pada GC Shimadzu 2010.

\section{Kondisi GC}

Unit GC yang digunakan adalah GC Shimadzu 2010. Detektor : FID, suhu : $260^{\circ} \mathrm{C}$, Metode : Methylester 37 New 3032017 $\mathrm{Kal}, \mathrm{gcm}$, Kolom : HP-88, Length: $100 \mathrm{~m}$.

\section{HASIL DAN PEMBAHASAN}

Hasil analisa dengan GC menunjukan pada ekstrak dedak non fermentasi terdapat 15 asam lemak dengan panjang rantai karbon 4 hingga 24 . Asam butirat merupakan asam lemak dengan rantai karbon terpendek yaitu 4, sedangkan asam lemak lignoserat merupakan asam lemak dengan rantai terpanjang yang terdapat dalam dedak. Beberapa asam lemak jenuh
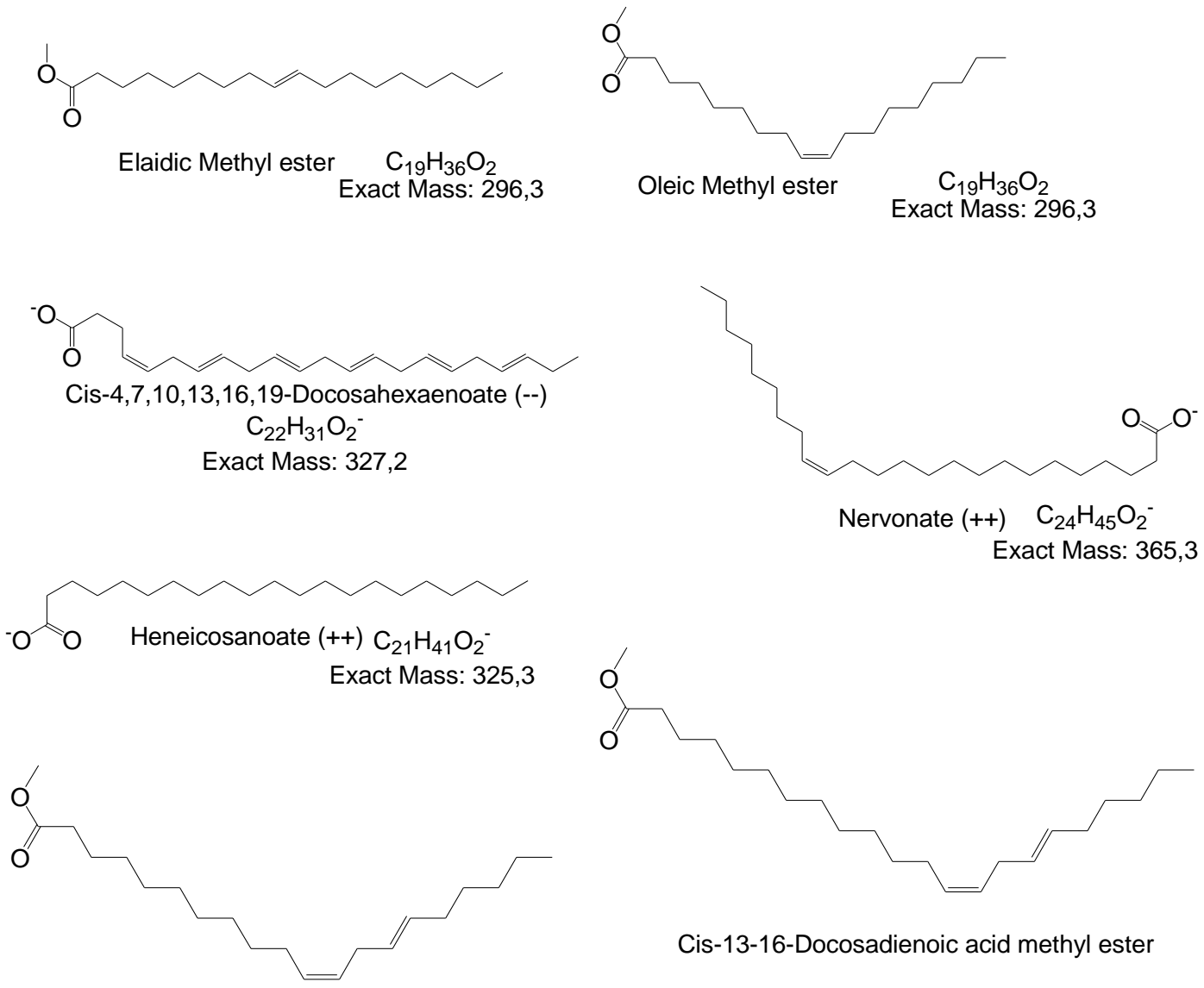

Cis-11,14-Eicosadienoic acid methyl ester $\mathrm{C}_{21} \mathrm{H}_{38} \mathrm{O}_{2}$

Exact Mass: 322,3

Cis-13-16-Docosadienoic acid methyl ester

$$
\mathrm{C}_{23} \mathrm{H}_{42} \mathrm{O}_{2}
$$

Exact Mass: 350,3

Gambar 1. Struktur kimia asam-asam lemak yang berubah secara drastis atau asam lemak baru yang terbentuk/hilang. 

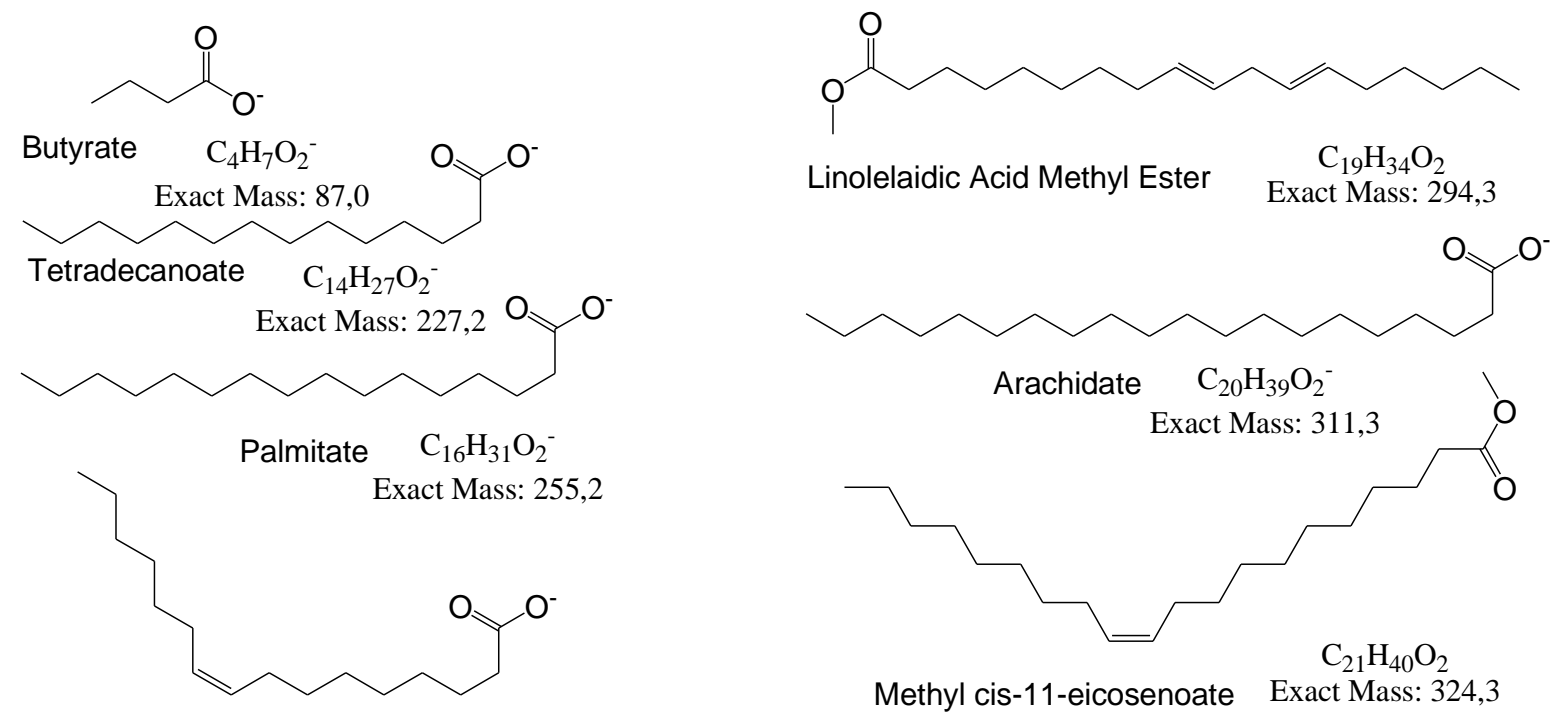

Methyl cis-11-eicosenoate Exact Mass: 324,3

Palmitoleat $\quad \mathrm{C}_{16} \mathrm{H}_{29} \mathrm{O}_{2}^{-}$

Exact Mass: 253,2
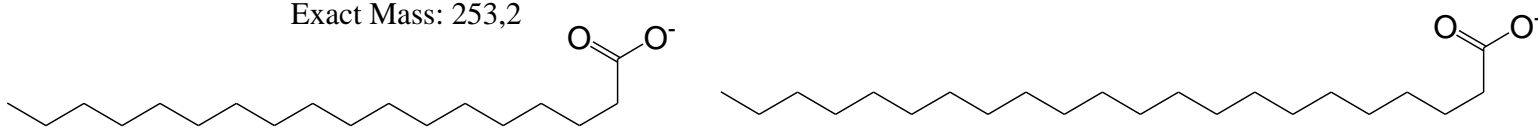

Octadecanoate $\quad \mathrm{C}_{18} \mathrm{H}_{35} \mathrm{O}_{2}$

Exact Mass: 283,3

Docosanoate $\quad \mathrm{C}_{22} \mathrm{H}_{43} \mathrm{O}_{2}^{-}$

Exact Mass: 339,3

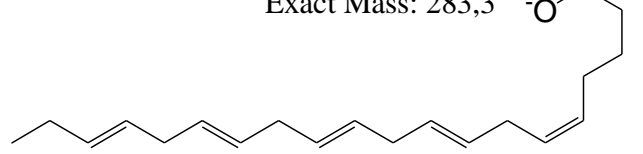

Cis-5,8,11,14,17-Eicosapentaenoate

$$
\mathrm{C}_{20} \mathrm{H}_{29} \mathrm{O}_{2}^{-}
$$

Exact Mass: 301,2

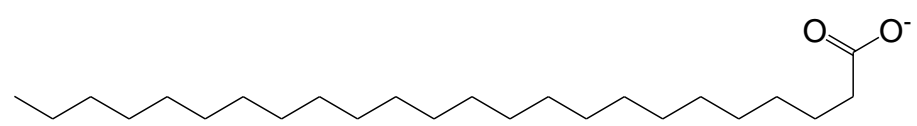

Lignocerate

$$
\mathrm{C}_{24} \mathrm{H}_{47} \mathrm{O}_{2}^{-}
$$

Exact Mass: 367,4

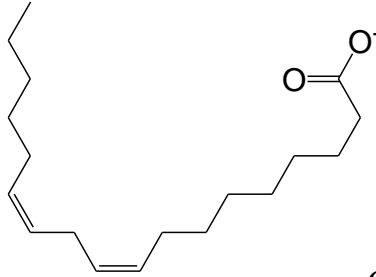

$\mathrm{C}_{18} \mathrm{H}_{31} \mathrm{O}_{2}$

Linoleate

Exact Mass: 279,2

Gambar 2. Struktur kimia asam-asam lemak yang konsentrasinya sedikit berubah atau tetap.

yang ditemukan dalam dedak tanpa fermentasi meliputi asam butirat, asam miristat, asam palmitat, asam stearat, asam arakhidat, asam Docosanoate, dan asam lignoserat. Sedangkan asam lemak tak jenuh meliputi Trans-9-Elaidic acid Methyl ester, Cis9-Oleic Methyl ester, Linolelaidic Acid Methyl Ester, M Linoleate, Methyl cis-11-eicosenoate, M Cis-5,8,11,14,17-Eicosapentaenoate, dan Cis-4,7, 10, 13,16,19-Docosahexaenoate.

Jamur laut merupakan sumber enzim lipase yang berperan penting dalam pemecahan lemak menjadi asam lemak dan gliserol (Knapp et al. 2013). Jamur telah digunakan dalam biokonversi asam lemak volatil menjadi "microbial asam lemak" yang potensial sebagai bahan untuk pembuatan biodisel (Jia Liu et al. 2017). Pada proses bioknoversi tersebut asam lemak pendek akan diubah menjadi asam lemak yang lebih panjang rantainya. Melalui bioengineering panjang rantai lemak dapat diatur sesuai dengan standar mutu suatu produk (Marella et al. 2018).

Komposisi asam lemak mengalami perubahan pada dedak yang difermentasi 
baik dalam kondisi salin mapun non-salin. Asam butirat, asam arakhidat dan asam lignoserat mengalami penurunan konsentrasi dedak yang difermentasi pada semua kondisi. Asam miristat, asam palmitoleat, asam linoleat, Methyl cis-11-eicosenoate mengalami penurunan pada kondisi unsaline tetapi naik pada kondisi salin. Asam stearat, Linolelaidic Acid Methyl Ester dan asam arakhidat mengalami kenaikan pada kondisi unsalin tetapi mengalami kelaikan pada kondisi Salin. Cis-5,8,11,14,17Eikosapentaenoat dan palmitat mengalami kenaikan pada semua kondisi fermentasi ( Tabel 1).

Proses fermentasi juga menghasilkan beberapa asam lemak baru yaitu: asam
Nervonate, eneicosanoate, Cis-11,14Eicosadienoic acid methyl ester, Cis-13-16Docosadienoic acid methyl ester. Isomerasi asam elaidat menjadi asam oleat merupakan fenomena yang sangat menarik (Gambar 3). Asam elaidat merapakan asam lemak tak jenuh dalam format trans yang dikenal tidak baik untuk kesehatan. Sedangkan asam oleat merupakan asam lemak dalam bentuk trans yang baik bagi kesehatan manusia.

Paparan $\mathrm{NaCl}$ menyebabkan perubahan komposisi biokimia jamur, terutama meningkatkan produksi polisakarida. Kapasitas P. chrysosporium untuk memperoleh toleransi yang meningkat terhadap stres garam dari waktu ke waktu,

Tabel 1. Hasil perubahan asam lemak trans menjadi asam lemak cis

\begin{tabular}{|c|c|c|c|c|c|c|}
\hline \multirow[b]{2}{*}{ No. } & \multirow[b]{2}{*}{ Asam lemak } & \multirow{2}{*}{$\begin{array}{c}\text { Non } \\
\text { fermented } \\
\text { Rata-rata } \\
\text { konsentrasi } \\
\text { (\% Relatif) }\end{array}$} & \multicolumn{2}{|c|}{ Fermented-unsaline } & \multicolumn{2}{|c|}{ Fermented-saline } \\
\hline & & & $\begin{array}{l}\text { Rata-rata } \\
\text { konsentrasi } \\
\text { (\% Relatif) }\end{array}$ & Keterangan & $\begin{array}{c}\text { Rata-rata } \\
\text { konsentrasi } \\
\text { (\% Relatif) }\end{array}$ & Keterangan \\
\hline 1 & M Butyrate & 4,48 & 3,69 & Turun & 2,90 & Turun \\
\hline 2 & M Tetradecanoate & 0,51 & 0,44 & Turun & 0,61 & Naik \\
\hline 3 & M Palmitate & 15,49 & 17,28 & Naik & 16,32 & Naik \\
\hline 4 & M Palmitoleate & 0,19 & 0,17 & Turun & 0,24 & Naik \\
\hline 5 & M Octadecanoate & 1,28 & 1,41 & Naik & 0,62 & Turun \\
\hline 6 & $\begin{array}{c}\text { Trans-9-Elaidic acid } \\
\text { Methyl ester }\end{array}$ & 36,82 & 0,70 & Turun drastis & 0,17 & Turun drastis \\
\hline 7 & $\begin{array}{c}\text { Cis-9-Oleic Methyl } \\
\text { ester }\end{array}$ & 0,76 & 39,18 & Naik drastis & 34,71 & Naik drastis \\
\hline 8 & $\begin{array}{l}\text { Linolelaidic Acid } \\
\text { Methyl Ester }\end{array}$ & 0,51 & 1,11 & Naik & 0,47 & Turun \\
\hline 9 & M Linoleate & 37,55 & 33,48 & Turun & 40,66 & Naik \\
\hline 10 & M Arachidate & 0,27 & 0,36 & Naik & - & Tidak ada \\
\hline 11 & $\begin{array}{l}\text { Methyl cis-1 1- } \\
\text { eicosenoate }\end{array}$ & 1,45 & 1,23 & Turun & 1,51 & Naik \\
\hline $\begin{array}{l}12 \\
13\end{array}$ & $\begin{array}{l}\text { M Docosanoate } \\
\text { M Lignocerate }\end{array}$ & $\begin{array}{l}0,11 \\
0,17\end{array}$ & $\begin{array}{l}0,12 \\
0,16\end{array}$ & $\begin{array}{l}\text { Naik } \\
\text { Turun }\end{array}$ & $\begin{array}{c}0,11 \\
-\end{array}$ & $\begin{array}{l}\text { Sama } \\
\text { Tidak ada }\end{array}$ \\
\hline 14 & $\begin{array}{l}\text { M Cis-5, } 8,11,14,17- \\
\text { Eicosapentaenoate }\end{array}$ & 0,21 & 0,42 & Naik & 0,76 & Naik \\
\hline 15 & $\begin{array}{l}\text { Cis- } 4,7,10,13,16,19- \\
\text { Docosahexaenoate }\end{array}$ & 0,19 & - & Tidak ada & - & Tidak ada \\
\hline 16 & M Nervonate & - & 0,14 & Baru & 0,36 & Baru \\
\hline 17 & $\begin{array}{c}\text { M Heneicosanoate } \\
\text { Cis-11,14- }\end{array}$ & - & 0,12 & Baru & 0,22 & Baru \\
\hline 18 & $\begin{array}{c}\text { Eicosadienoic acid } \\
\text { methyl ester } \\
\text { Cis-13-16- }\end{array}$ & - & - & - & 0,21 & Baru \\
\hline 19 & $\begin{array}{l}\text { Docosadienoic } \\
\text { acid methyl ester }\end{array}$ & - & - & - & 0,14 & Baru \\
\hline
\end{tabular}


<smiles>CCCCCCCCC=CCCCCCCC(=O)OC</smiles>

Elaidic Methyl ester
Isomerasi

$$
\mathrm{C}_{19} \mathrm{H}_{36} \mathrm{O}_{2}
$$

Exact Mass: 296,3

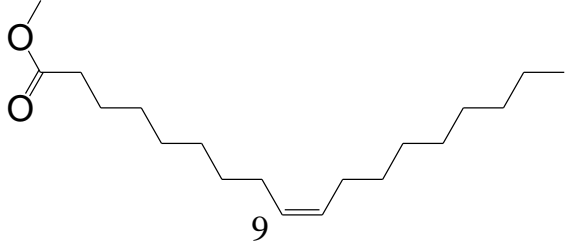

Oleic Methyl ester

Exact Mass: 296,3

Gambar 3. Struktur kimia asam-asam lemak yang berubah secara drastis atau asam lemak baru yang terbentuk/hilang.

dapat dikaitkan dengan kapasitas yang lebih tinggi untuk produksi dan / atau retensi zat terlarut (Jeon et al., 2017). Menariknya, jamur ini, setelah terpapar ke tingkat salinitas rendah, meningkat basalnya (di bawah kondisi kontrol) dari beberapa metabolit (misalnya senyawa dengan karboksil, lipid, protein, polisakarida), seperti yang dikonfirmasi oleh peningkatan daerah puncak eksternal yang diperoleh oleh spektrum infra-merah (penambahan 53, 10, 9 dan $43 \%$ untuk karboksil, lipid, protein dan polisakarida, masing-masing).

Perbedaan intensitas puncak diamati antara konsentrasi kontrol dan $\mathrm{NaCl}$ untuk NPENaCl, perbedaan tersebut tidak diamati untuk PE-NaCl. Hasil ini dapat menunjukkan kapasitasnya untuk menyesuaikan diri dengan stres osmotik setelah pemaparan yang berkepanjangan. Sebenarnya, kemampuan jamur untuk menyesuaikan diri dengan stres kimia sudah dikenal dan telah banyak digunakan untuk meningkatkan beberapa karakteristik dari organisme ini.

Salinitas dapat mempengaruhi laju pertumbuhan dan komposisi hifa jamur, sehingga bahan bioaktifnya juga kemungkinan terpengaruh (Venâncio et al. 2017). Pada penelitian lain, salinitas rendah dapat meningkatkan produktivitas dari suatu fermentortor dibandingkan tanpa adanya $\mathrm{NaCl}$, tetapi pada salinitas tinggi menghambat proses produksi senyawa target (Wen et al. 2018). Namun demikian, salititas optimum berbeda antara satu microorganisme dengan organisme yang lain tergantung sifat alamiah dari mikroba yang digunakan dalam proses fermentasi.

Analisis data GC MS menunjukan bahwa salah satu senyawa mayor dalam dedak yaitu asam elaidat (trans-9 C18:1) mengalami trans-cis isomerasi. Asam lemak trans merupakan asam lemak yang berbahaya bagi kesehatan manusia karena dapat menyebabkan penyakit jantung. Proses isomerasi cis/trans pada asam lemak biasanya terjadi dalam proses penggoregngan (Cheng et al. 2018). Kemampuan jamur $T$. harzianum dalam proses isomerasi trans-cis pada asam lemak elaidat menjadi asam lemak oleat sangat bermanfaat dalam meningkatkan mutu bahan pangan atau bahan pakan ternak. Asam lemak oleat merupakan asam lemak yang baik bagi kesehatan karena dapat menurunkan tekanan darah dan plasma kolesterol (Lee et al. 2019). Asam oleat juga bermanfaat sebagai bahan pembuat "drug carier" untuk obat kanker (ElMasry et al. 2018). Fermentasi telah digunakan dalam berbagai bidang misalnya untuk memproduksi pigmen, industri makanan memproduksi asam lemak, dan pengolahan limbah (Liv et al., 2019, Xuan et al., 2018).

\section{KESIMPULAN}

Komposisi asam lemak mengalami perubahan pada dedak yang difermentasi baik dalam kondisi salin mapun non-salin. Proses fermentasi juga menghasilkan beberapa asam lemak baru yaitu: asam Nervonate, eneicosanoate, Cis-11,14Eicosadienoic acid methyl ester, Cis-13-16Docosadienoic acid methyl ester. Isomerasi asam elaidat menjadi asam oleat merupakan fenomena yang sangat menarik.

\section{UCAPAN TERIMA KASIH}

Penelitian ini merupakan bagian dari hibah RPI yang dibiayai dengan sumber 
dana Selain APBN DPA SUKPA LPPM Universitas Diponegoro Tahun Anggaran 2017.

\section{DAFTAR PUSTAKA}

Amira M.G.E., Ahmed A.L. \& Tatsufumi O. 2009. Modulation of carcinogen metabolizing enzymes by chromanone $A$; a new chromone derivative from algicolous marine fungus Penicillium sp. Environ. Toxicol. Pharmacol. 28:317-322

Cheng, N, Zhang J., Yin J., \& Li S. 2018. Computational and Experimental Research on Mechanism of Cis/Trans Isomerization of Oleic Acid. Heliyon 4(9).

ElMasry, S.R., Hathout R.M., Abdel-Halim M., \& Mansour S.. 2018. In Vitro Transdermal Delivery of Sesamol Using Oleic Acid Chemically-Modified Gelatin Nanoparticles as a Potential Breast Cancer Medication. J. Drug Delivery Sci. Technol. 48: 30-39.

Hadipernata, M., Supartono W., \& Falah M.A.F. 2012. Proses Stabilisasi Dedak Padi (Oryza sativa L.) Menggunakan Radiasi Far Infra Red (Fir) Sebagai Bahan Baku Minyak Pangan. J. Aplikasi Teknol. Pangan. 1 (4):103-107.

Jeon, E.Y., Song, J. W., Cha, H. J., Lee, S.M., Lee, J., \& Park, J.B. 2018. Intracellular transformation rates of fatty acids are influenced by expression of the fatty acid transporter FadL in Escherichia coli cell membrane. J. Biotechnol. 281:161167.

Knapp, I.S.S., Williams G.J, Carballo J.L. CruzBarraza J.A., Garner J.P.A, \& Bell J.J, 2013. Restriction of sponges to an atoll lagoon as a result of reduced environmental quality. Mar. Poll. Bull. 66(1-2):209-220. doi: 10.1016/j.marpol bul.2012.08.017.

Lee, D-H, Kulkarni K.P., Kim B.O, Seok Y.M., Song J.T., \& Lee J.D. 2019. Comparative Assessment of Quality Characteristics of Chungkookjang Made from Soybean Seeds Differing in Oleic Acid Concentration. J. Functional Foods. 52:529-36

Liu, J., Gao T., Luo Y., Chai X., Wu J., Zhao W., Jiao P., Luo F., \& Lin Q.. 2019. Enhancement of Monascus Pigment Productivity via a Simultaneous Fermentation Process and Separation
System Using Immobilized-Cell Fermentation. Biore. Technol. 272:552560.

Liu, J., Yuan M., Liu JN.., \& Huang X.F. 2017. Bioconversion of Mixed Volatile Fatty Acids into Microbial Lipids by Cryptococcus Curvatus ATCC 20509. Bioresource Technology 241:645-51.

Marella, E.R., Holkenbirnk C., Siewers V., \& Borodina I., 2018. Engineering microbial fatty acid metabolism for biofuels and biochemical. Current Opinion in Biotechnol. 50:39-46. DOI : 10.1016/j.copbio.2017.10.002.

Mazidi, M., Katsiki, N., Mikhailidis, D. P., \& Banach, M. 2018. Link between plasma trans-fatty acid and fatty liver is moderated by adiposity. Int. J. Cardiology. 272:316-322.

Murniasih, T., Wibowo J.T., Putra M.Y., Untari F. \& Maryani M.. 2016. Pengaruh nutrisi dan suhu terhadap selektivitas potensi antibakteri dari bakteri yang berasosiasi dengan spons. Jurnal Kelautan Tropis Vol. 21 (1):65-70

Swathi, J. 2013. Marine fungal metabolites as a rich source of bioactive compounds. African J. Biochem. Res. 7(10):184-196.

Venâncio, C., Pereira R., Freitas A.C., RochaSantos T.A.P., da Costa J.P., Duarte A.C. \& Lopes I. 2017. Salinity induced effects on the growth rates and mycelia composition of basidiomycete and zygomycete fungi. Environ. Poll. 231:1633-1641. doi: 10.1016/j.envpol.20 17.09.075.

Wang, X., Wang, X. \& Wang, T. 2017. An effective method for reducing free fatty acid content of high-acid rice bran oil by enzymatic amidation. J. Indust. Eng. Chem. 48:119-124. doi: 10.1016/j.jiec. 2016.12.028.

Wen, Q., Ji Y., Hao Y., Huang L., Chen Z., \& Sposob M. 2018. Effect of Sodium Chloride on Polyhydroxyalkanoate Production from Food Waste Fermentation Leachate under Different Organic Loading Rate. Biores. Technol. 267:133-40.

Wikanta, D.K. \& Tembalang, P. 2012. Pengembangan Proses Thermokimia Untuk Peningkatan Konversi Asam Lemak Melalui Interfacial Activation Lipase Buah Segar Kelapa Sawit 
Dengan Tuning Up. Media Komunikasi Rekayasa Proses dan Teknologi Tepat Guna 8(1):13-18.

Xuan, N.H., Ferng S., Ting, C.H, LU, Y.C, Yeh, Y.F, Lai, Y.R, Chou, R.Y.H, Hwang, J.Y, \& Hsu, C.K. 2018. Food Science and
Technology Effect of Initial 5 Days Fermentation under Low Salt Condition on the Quality of Soy Sauce. LWT. 92(300): 234-41. 